\title{
Horizontal distribution of tintinnids in the open waters of the South Adriatic (Eastern Mediterranean)*
}

\author{
FRANO KRSIINIC ${ }^{1}$ and BRANKA GRBEC ${ }^{2}$ \\ ${ }^{1}$ Institute of Oceanography and Fisheries, Split, Laboratory of Plankton Ecology, Dubrovnik, Kneza Damjana Jude 12, \\ HRV-20000, Dubrovnik, Croatia. E-mail, krsinic@labdu.izor.hr \\ ${ }^{2}$ Institute of Oceanography and Fisheries, Split, Laboratory of Physical Oceanography, Ivana Meštrovića 63, HRV-21000, \\ Split, Croatia.
}

\begin{abstract}
SUMMARY: The horizontal distribution of oceanic tintinnids was studied in the South Adriatic Sea during 11 cruises undertaken between 1980 and 1990. Of the 70 species identified, there were 47 surface, 16 subsurface, 4 mid-water, and 3 deepsea species. The dominant surface and subsurface species were Dictyocysta mitra and Codonella aspera. Undella claparedei. Parundella lohmanni predominated in the mid-water layers and Xystonellopsis scyphium in the deep-sea layers. Ingression of water masses from the Ionian Sea and the formation of a cyclonic gyre are important in determining the horizontal distribution of tintinnids in the South Adriatic. Periods of strong advection of waters from the Ionian Sea impose a longitudinal type of distribution on tintinnids, characterized by high species diversity, low abundance, and the transport of southern species to the Middle and North Adriatic. This differs from "eddy type" distribution, in which species diversity is lower, population density is greater in all layers, and the transport of species northward ceases. It may be assumed that mesopelagic and deep-sea tintinnids depend on food resources transported by sinking Middle Adriatic dense waters (MadDW).

Keywords: ciliates, tintinnids, distribution, Adriatic Sea.

RESUMEN: Distribución HORIZONTAL DE TINTÍNIDOS EN AGUAS DEL SUd-ADRIATICo (MEDITERRÁNEO ORIENTAL). - La distribución horizontal de los tintínidos oceánicos fue investigada en el Sur del Mar Adriático en 11 campañas oceanográficas realizadas entre 1980 y 1990. De las 70 especies identificadas, 47 se encontraron en la superficie, 16 en la subsuperficie, 4 en profundidades medias y 3 en aguas profundas. Las especies dominantes en aguas superficiales y subsuperficiales eran Dictyocysta mitra, Codonella aspera, y Udenella claparedei. Parundella lohmani predominaba en capas medianamente profundas y Xystonellopsis scyphium en aguas profundas. La intrusion de masas de agua provenientes del Mar Jónico y la formación de un remolino ciclónico son importantes en la determinación de la distribución horizontal de los tintinidos en el Sud-Adriático. Períodos de fuerte advección de aguas del mar Jónico impone un tipo de distribución longitudinal de tintínidos, caracterizados por una alta diversidad de especies, baja abundancia y transporte de especies del Sur al Centro y NorAdriático. Esta difiere del tipo de la distribución típica de remolinos, en los cuales la diversidad de especies es baja y la densidad de la población es más alta en todas las profundidades y el transporte de especies hacia el Norte cesa. Está asumido que los tintínidos mesopelágicos y de aguas profundas dependen de las fuentes de substrato transportados por sedimentación desde las aguas medianamente profundas.
\end{abstract}

Palabras clave: ciliados, tintinidos, distribución, mar Adriatico.

\section{INTRODUCTION}

Loricate ciliates or tintinnids are important members of the plankton in all marine habitats, but most

*Received January 11, 2005. Accepted June 17, 2005. work so far has focused on coastal ecosystems (Hargraves, 1981; Burkill, 1982; Verity and Stocker, 1982; Capriulo and Carpenter 1983; Verity, 1986), in which estuarine and neritic tintinnids are occasionally exceptionally abundant (Paranjape, 1987; Kršinić, 1987; Modigh and Castaldo, 2002). The 
role of tintinnids in the oligotrophic waters of tropical and subtropical regions, especially in the Mediterranean, is poorly known. Oceanic tintinnids are less abundant, and many species are quite rare. Adequate sampling methods are a matter of great concern, as the traditional method of using plankton nets has proved to be unsatisfactory for studying their qualitative and quantitative composition.

In the wake of important expeditions carried out at the beginning of the $20^{\text {th }}$ century (Brandt, 1906, 1907; Laackmann, 1910; Jörgensen, 1924), there have been relatively few new data on the biogeography of oceanic tintinnids. Recent authors have reported aspects of their global distribution (Pierce and Turner, 1993), in the North Sea (Cordeiro et al., 1997), south-western Atlantic (Thompson et al., 1999), and the Mediterranean Sea (Dolan et al., 1999; Dolan, 2000; Pitta and Giannakourou, 2000; Pitta et al., 2001; Modigh et al., 2003).

The present paper contributes to the knowledge of oceanic tintinnids in the South Adriatic Sea by analysing data derived from eleven sampling cruises undertaken from 1980 to 1990 aboard the R/V Andrija Mohorovičić. Earlier reports on the same data dealt with the population structure and vertical distribution of protozoans and microcopepods (Kršinić, 1998; Kršinić and Grbec, 2002), as well as a more detailed treatment of the vertical distribution of all tintinnids (Kršinić, 1982), and the family Xystonellidae (Kršinić, 1988). This contribution analyzes the data to elucidate features of the qualitative composition, horizontal distribution, and numerical abundance of tintinnids in the South Adriatic and the Palagruža Sill. Research on the horizontal distribution of oceanic tintinnids has generally involved samples taken during a single cruise, where samples were taken most frequently from the surface layer. This research reveals data on the horizontal distribution of oceanic tintinnids in the broadest and deepest regions of the Adriatic Sea, as well as the vertical distribution and seasonal changes in taxonomic composition and abundance.

\section{MATERIAL AND METHODS}

Samples were collected during 11 cruises aboard the R/V Andrija Mohorovičić (Fig. 1), along all three transects in August 1986, April 1987, November 1989, March 1990 and May 1990; the transects Dubrovnik - Bari and the southern-

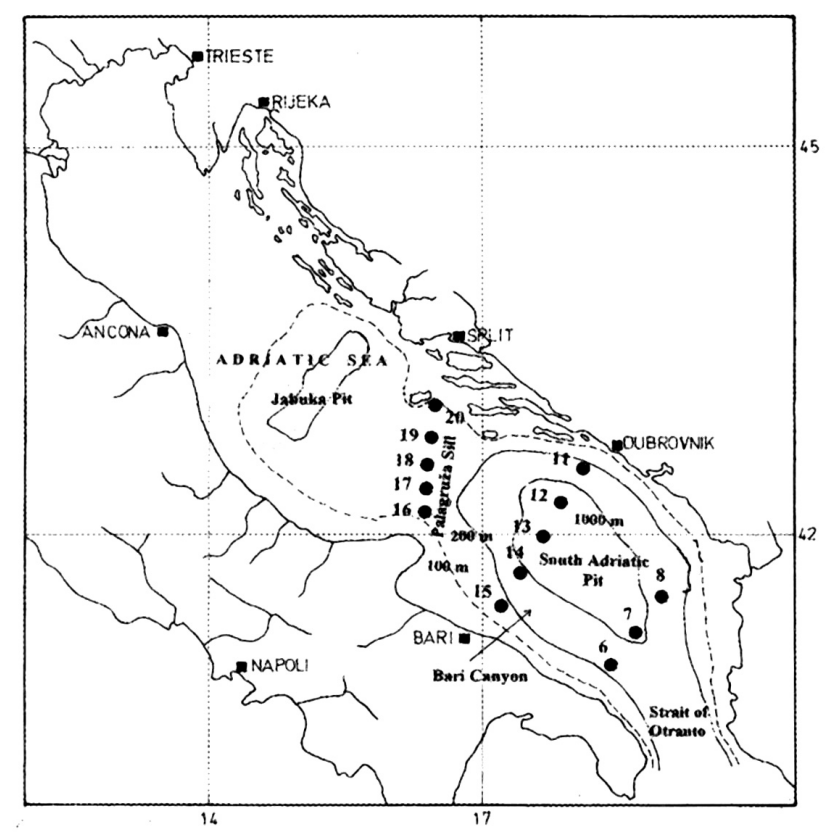

FIG. 1. - Research area and sampling stations.

most transect in January 1980 and April 1986; the transects Dubrovnik - Bari and Palagruža Sill in October 1985, June 1988, September 1988 and July 1989.

Samples were taken with a $53-\mu \mathrm{m}$ Nansen net (45 cm diameter) equipped with a closing system at a hauling speed of $0.5 \mathrm{~m} \mathrm{~s}^{-1}$ within the following layers: A (0-50 m), B (50-100 m), C (100-200 m), D (200-300 m), E (300-400 m), F (400-600 m), G (600-800 m), H (1000-800 m). Organisms were preserved in a neutrally buffered formaldehydeseawater solution at a final concentration of about $2.5 \%$. Counting and species identification were performed with an Olympus inverted microscope at magnifications of 100x and 400x. One-sixteenth of each sample was analyzed for common species, while the entire catch was examined for rare species. A GeneralOceanics, Inc. R2 Flowmeter (Model 2030) was used to estimate the volume of filtered seawater.

Tintinnid identifications were based on lorica morphology using the taxonomic references of Daday (1886, 1887), Entz (1904, 1909), Brandt (1906, 1907), Laackmann (1913), Jörgensen (1924), Kofoid and Campbel (1929, 1939), and Balech (1959, 1968, 1975). Only typical forms for the species were considered based on the author's experience in the morphological variability of lorica in the Adriatic Sea. For this reason, we were critical when identifying the species based only on Kofoid and Campbel (1929), as previously recommended 
by Laval-Peuto (1981), and Laval-Peuto and Brownlee (1986). Only complete lorica or those with plasmatic body parts were considered for the quantitative analysis, as the empty lorica of surface and subsurface species can contribute to interpreting the horizontal and vertical distribution of tintinnids incorrectly. According to the above-mentioned literature and Kršinić (1980), the species are considered as oceanic or neritic-coastal.

Temperature was measured with Richter-Wiese reversing thermometers and salinity was determined with an Autolab 601-MK III inductive salinometer. During cruises in March 1990 and May 1990, vertical temperature and conductivity profiles were measured with a SBE (Sea Bird Electronic) CTD multi-parameter probe. Temperature and salinity data were obtained from the database of the Hydrographic Institute of the Republic of Croatia (Split).

Cluster analysis (Single linkage, Euclidean distances) was used to identify the similarities between tintinnid communities in all stations during each cruise. Numerical abundance was used for analysing all registered species at both surface and subsurface layers at stations where samples were taken. Statistical analysis and graphical presentations were solved with STATISTICA for Windows (StatSoft, 2000). In order to identify areas (stations) with a similar abundance of tintinnids, the principal component analysis (PCA) was performed on the correlation matrix of the total abundance collected during 6 cruises with complete sets of samples (August 1986; April 1987; June and September 1988; November 1989; May 1990) across the DubrovnikBari and Palagruža Sill transects at 10 stations at both surface and subsurface layers. PCA was performed following procedures already done at a small zooplankton distribution in the Otranto Strait (Kršinić and Grbec, 2002). The Varimax rotation (Richman, 1986), of significant PC components was used in order to obtain a better insight into the biological behaviour of the area in the central part of the southern Adriatic and Palagruža Sill.

\section{RESULTS}

\section{Study area}

The Adriatic Sea can be divided into two quite separate geo-morphological regions: the South Adriatic, and the Middle with the North Adriatic. In the South Adriatic, the central area is a deep pit with a maximum depth of $1230 \mathrm{~m}$. A shallow continental shelf less than $100 \mathrm{~m}$ in depth is located north of the Palagruža Sill, except in the Jabuka Pit region where the greatest depth is $270 \mathrm{~m}$, as well as the $150 \mathrm{~m}$ deep canyon that connects these depressions. The South Adriatic covers $41 \%$ of the total surface area of the Adriatic Sea. The South Adriatic is influenced on one side, across the Strait of Otranto for about 70 $\mathrm{km}$ at depths of $800 \mathrm{~m}$, by water masses from the Ionian Sea, eastern Mediterranean ISW (Ionian surface water) and LIW (Levantine intermediate waters), (Zore-Armanda, 1963; Buljan and ZoreArmanda, 1976). On the other side, it is influenced by the shallow Middle and North Adriatic, where NadDW (North Adriatic dense waters) and MadDW (Middle Adriatic dense waters) water masses are formed (Vilibić and Orlić, 2002).

The surface circulation over the South Adriatic Pit is influenced by a topographically controlled cyclonic gyre (Orlić et al., 1992). An inflowing current prevails along the eastern Adriatic coast, and an outgoing current prevails along the western coast (Zore-Armanda, 1968).

A minimum salinity was found in August 1986 $(38.54 \pm 0.18 \mathrm{psu})$ and a maximum in November $1989,38.91 \pm 0.09$ psu. A typical thermocline formed in the surface layer during warmer months. A maximum temperature, $26.32^{\circ} \mathrm{C}$, was found in August 1986. Average temperatures below $100 \mathrm{~m}$ were within a narrow range, from $13.20 \pm 0.19^{\circ} \mathrm{C}$ in April 1986 to $13.55 \pm 0.38^{\circ} \mathrm{C}$ in November 1989 . Oxygen hyper-saturation was typical for the surface zone, while an oxygen minimum occurred between 100 and $300 \mathrm{~m}$ (range 69-88 \%, minimum $51.9 \%$ at 100 m P-12 in May 1990). A more detailed presentation of hydrographic data for the South Adriatic Pit during Mohorovičić cruises are found in Bićanić (1993), and Vilibić and Orlić (2001, 2002).

\section{Qualitative composition}

A total of 70 species of tintinnids representing 12 families were recorded. See Table 1 for a list of species. In terms of vertical occurrence, 47 were found in the surface layer, 16 in the subsurface layer, 4 were mesopelagic, and 3 were deep-sea species. Only three species were neritic-coastal (Tintinnopsis radix, Stenosemella ventricosa, and Codonellopsis schabi), while the rest were oceanic.

Fifty species were found during October 1985, but significantly fewer were found subsequently: 
TABLE 1. - List of species; surf.= surface species; subsurf. = subsurface species; mezop.=mezopelagic species, deepsea= deep-sea species.

TINTINNINA Kofoid and Campbell, 1929

CODONELLIDAE Kent, 1881

1. Tintinnopsis angulata Daday, 1887

2. Tintinnopsis radix (Imhof) Brandt, 1907

3. Codonella aspera Kofoid and Campbell, 1929

4. Codonella galea Haeckel, 1873

5. Codonella amphorella Biedermann, 1893

6. Codonella apicata Kofoid and Campbell, 1929

7. Codonaria cistellula (Fol) Kofoid and Campbell, 1939

8. Poroecus apiculatus (Cleve) Cleve, 1902

9. Poroecus tubulosus Balech, 1968

CODONELLOPSIDAE Kofoid and Campbell, 1929

10. Stenosemella ventricosa (Clap. and Lach.) Jörgensen, 1924 (surf.)

11. Codonellopsis orthoceras (Haeckel) Jörgensen, 1924 (surf.)

12. Codonellopsis schabi (Brandt) Kofoid and Campbell, 1929 (surf.)

METACYLIDIDAE Kofoid and Campbell, 1929

13. Climacocylis scallaroides Kofoid and Campbell, 1929

CYTTAROCYLIDIDAE Kofoid and Campbell, 1929

14. Cyttarocylis eucecryphalus (Haeckel) Kofoid, 1912

15. Cyttarocylis cassis (Haeckel) Fol, 1881

16. Petalotricha ampulla (Fol) Kent, 1882

PTYCHOCYLIDIDAE Kofoid and Campbell, 1929

17. Favella azorica (Cleve) Jörgensen, 1924

EPIPLOCYLIDIDAE Kofoid and Campbell, 1939

18. Epiplocylis undella (Ostenfeld and Schmidt) Balech, 1962

19. Epiplocylis acuminata (Daday) Jörgensen, 1924

ASCAMPBELLIELLIDAE Corliss, 1960

20. Craterella armilla Kofoid and Campbell, 1929

RHABDONELLIDAE Kofoid and Campbell, 1929

21. Rhabdonella spiralis (Fol) Brandt, 1907

22. Rhabdonella elegans Jörgensen, 1924

23. Rhabdonella amor (Cleve) Brandt, 1906

XYSTONELLIDAE Kofoid and Campbell, 1929

24. Parundella lohmanni (Jörgensen) Kofoid and Campbell, 1929 (mezop.)

25. Parundella messinensis (Brandt) Jörgensen, 1924

26. Parundella caudata (Ostenfeld) Cleve, 1900

27. Parundella aculeata Jorgensen, 1924

28. Xystonella longicauda (Brandt) Laackmann, 1911

Campbell, 1929 (surf.)

30. Xystonella treforti (Daday) Laackmann, 1909

31. Xystonellopsis brandti (Laackmann) Jörgensen, 1924

32. Xystonellopsis paradoxa (Cleve) Jörgensen, 1924

33. Xystonellopsis scyphium Jörgensen, 1924

34. Xystonellopsis cymatica (Brandt) Jörgensen, 1924

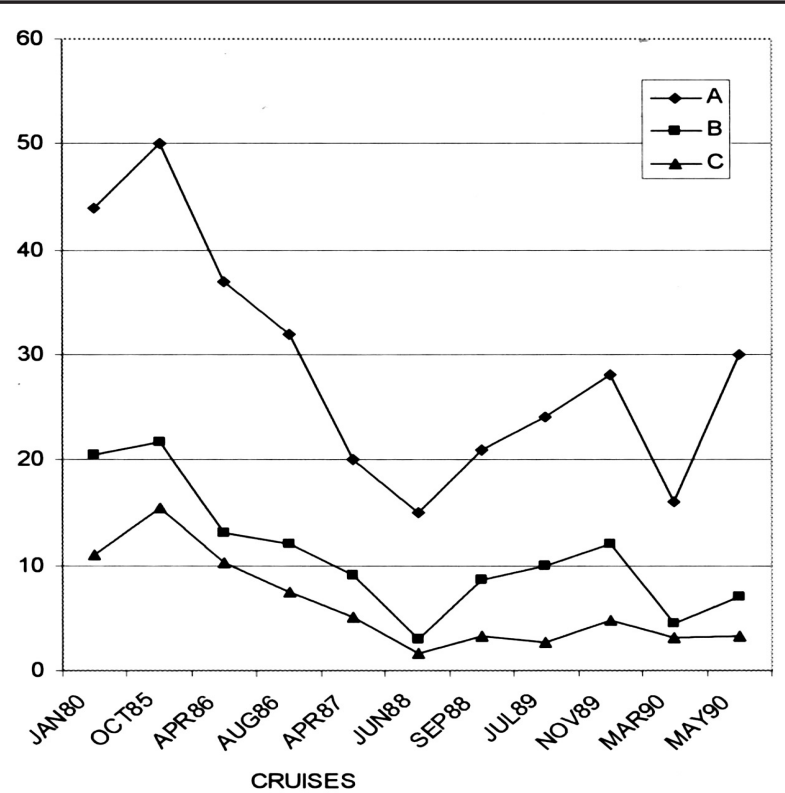

FIG. 2. - Variability of the total number of species from $100 \mathrm{~m}$ to the surface for cruises at all stations (line A); the number of species only for stations S7, 8, 12-14 (line B) and only for stations S6, 11, 15-20 (line C).

(subsurf.)

(surf.)
35. Xystonellopsis aciculifera (Jörgensen) Balech, 1968

(deepsea)

UNDELLIDAE Kofoid and Campbell, 1929

36. Undella clevei Jörgensen, 1924

37. Undella hyalina Daday, 1887

38. Undella claparedei (Entz) Daday, 1887

39. Undella biangulata Kofoid and Campbell, 1929

40. Undella pentagona (Jörgensen) Balech, 1975

41. Undella subcaudata acuta (Jörgensen) Balech, 1975

42. Undella subcaudata subcaudata (Jörgensen) Balech, 1975 (subsurf.)

43. Amplectella collaria (Brandt) Kofoid and Campbell, 1929 (surf.)

44. Amplectella tricollaria (Laackmann) Balech, 1975 (surf.)

45. Undellopsis marsupialis (Brandt) Kofoid and Campbell, 1929 (subsurf.)

DICTYOCYSTIDAE Haeckel, 1873

46. Dictyocysta elegans Ehrenberg, 1854

47. Dictyocysta lepida Ehrenberg, 1854

(surf.)

48. Dictyocysta muelleri (Imhof) Jörgensen, 1924

(surf.)

(subsurf.)

(subsurf.)

(subsurf.)

50. Dictyocysta entzi Jörgensen, 1924

TINTINNIDAE Claparède and Lachmann, 1858

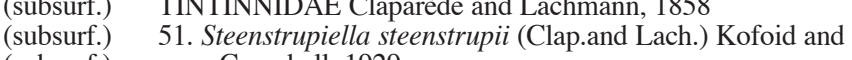
Campbell, 1929

52. Daturella spp.

(surf.)

53. Ormosella trachelium (Jorgensen) Kofoid and Campbell, 1929

(subsurf.)

54. Ascampbeliella acuta (Kofoid and Campbell) Corliss, 1960 (surf.)

55. Albatrosiella agassizi Kofoid and Campbell, 1929 (surf.)

56. Amphorides amphora (Clap. and Lach) Kofoid and Campbell, 1929

57. Amphorides tetragona Jörgensen, 1924

(surf.)

(mezop.)

58. Amphorides quadrilineata (Clap. and Lach) Jörgensen, 1924 (surf.)

59. Amphorides quadril. var. minor Jörgensen, 1924 (surf.)

60. Amphorides laackmanni Jörgensen, 1924 (surf.)

61. Dadayiella ganymedes (Entz) Kofoid and Campbell, 1929 (surf.)

62. Dadayiella pachytoecus (Jörgensen) Kofoid and Campbell, 1929

(surf.)

63. Eutintinnus fraknoi (Daday) Kofoid and Campbell, 1939 (surf.)

64. Eutintinnus lusus-undae (Entz) Kofoid and Campbell, 1939 (surf.)

65. Eutintinus latus (Jörgensen) Kofoid and Campbel, 1939 (surf.)

66. Eutintinnus elegans (Jörgensen) Kofoid and Campbell, 1939 (surf.)

67. Eutintinnus tubulosus (Ostenfeld) Kofoid and Campbell, 1939 (surf.)

68. Eutintinnus apertus Kofoid and Campbell, 1929 (surf.)

69. Salpingella glockentoegeri (Brandt) Kofoid and Campbell, 1929

70. Salpingella decurtata Jörgensen, 1924

(surf.)

(surf.)

only 15 species were collected in June 1988 (Fig. 2 , line A). The number of species increased again from September 1988, except during March 1990. The pattern of the total number of species is similar to that of the number of species in the $0-100 \mathrm{~m}$ layer for stations S 7, 8, and S12-14 (Fig. 2, line B); and for stations S6, 11, and S15-20 (Fig. 2, line C). In general, tintinnid species were poorly represented at stations near the shoreline and at the Palagruža Sill.

\section{Horizontal distribution in surface and subsur- face layers}

As a rule, a maximum density was found at one or two stations in the central area of the South Adriatic Pit, in surface or subsurface layers with higher values as presented in Table 2. The minimum, maximum and median values for four groups of stations, excluding extremes, as well as for both 
TABLE 2. - Range numerical abundance of tintinnids (No. $\mathrm{m}^{-3}$ ) for two groups of stations during 11 cruises in the open waters of the South Adriatic $(A=50-0 m ; B=100-50 m ; n=$ number of samples $)$.

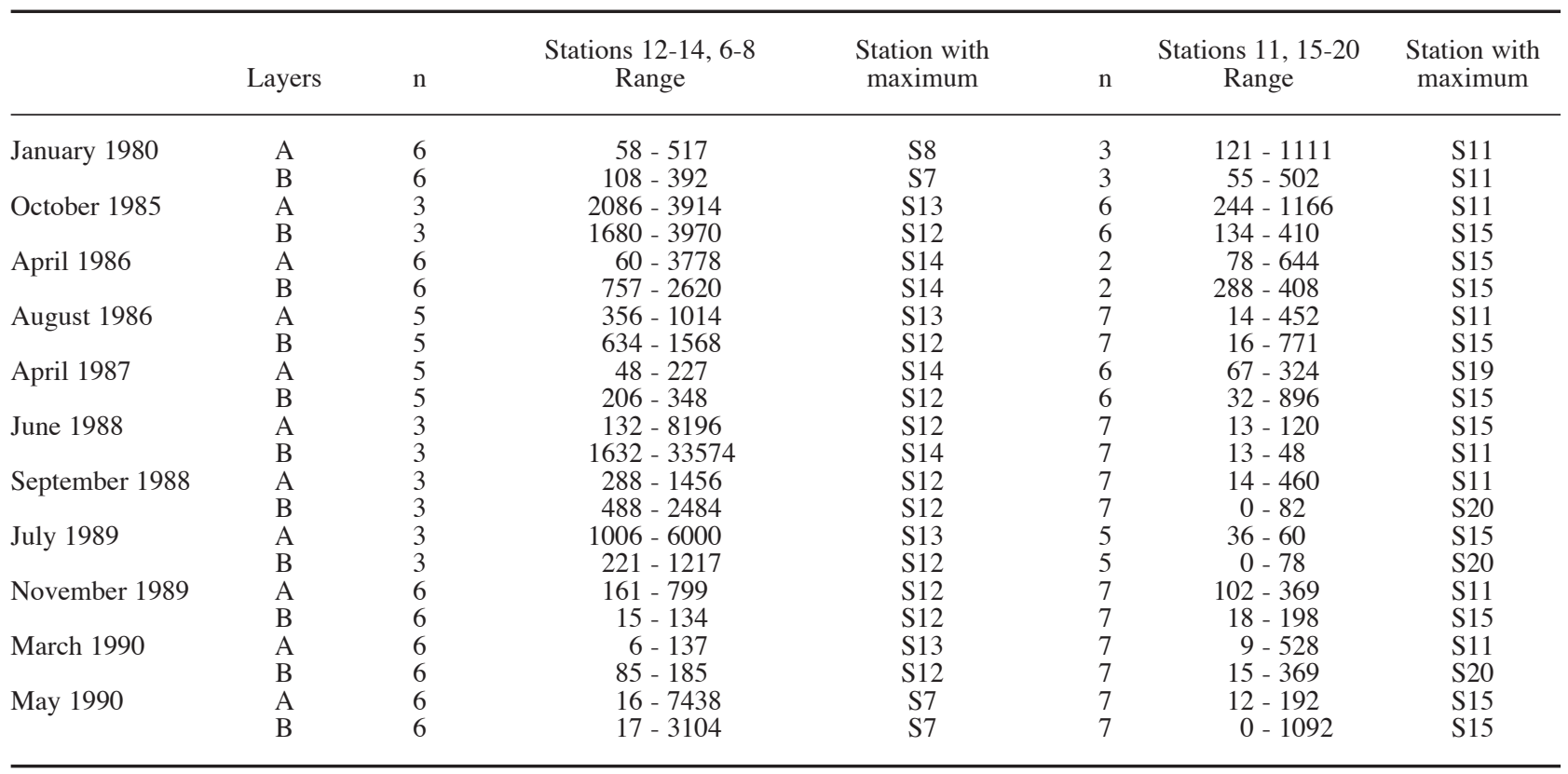

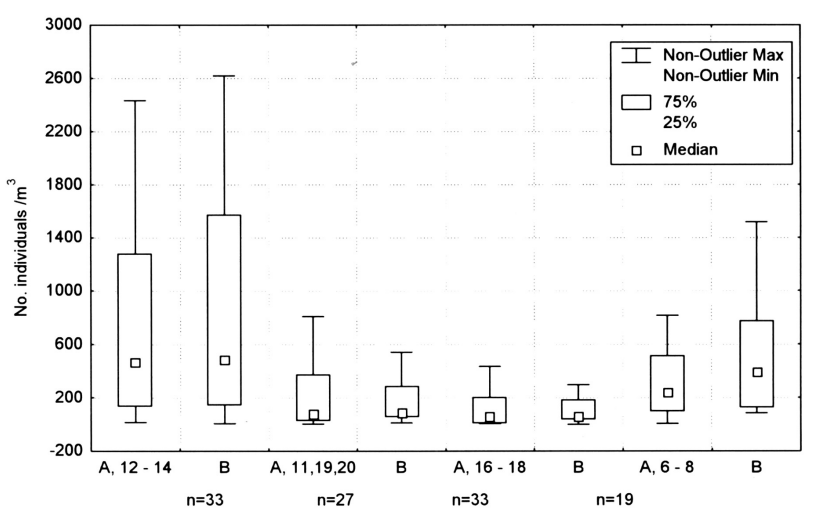

FIG. 3. - Box diagram of non-transformed data for the total number of tintinnids in layers $\mathrm{A}, 0-50 \mathrm{~m} ; \mathrm{B}, 50-100 \mathrm{~m}$ for four different areas.

surface and subsurface layers are presented in Figure 3 . The lowest values were noted at perimeter stations towards the shoreline $(\mathrm{S} 11,19,20)$ and in the area of the Palagruža Sill $(\mathrm{S} 16,17,18)$. The most common type of tintinnid horizontal distribution was characterized by a core of pronounced abundance in the central area of the South Adriatic Pit, which included stations S12, 13, 14, and 7 (October 1985; April and August 1986; June and September 1988; July 1989). For the mentioned cruises, these stations stand out from others when displayed in dendrograms, Figure 4. The second type of horizontal distribution is presented by longitudinal isopleths of abundance in one or both layers (January 1980; November 1989; March and May 1990). Differences in population density between layers were usually very low. The cluster analysis showed a similarity between most stations during these cruises (Fig. 4). Based on the PC analysis performed on total tintinnid abundance, three significant eigenvectos (according to the rule N) were extracted, which accounted for $71 \%$ of the total variance. After Varimax rotation, and based on the distribution of PC loadings, it was possible to separate three different areas in the Middle Adriatic Sea, as can be seen in Figure 5.

\section{Horizontal distribution in mesopelagic and deep-sea layers}

The total tintinnid abundances in the mesopelagic layer, especially between 100-200 m, were influenced greatly by the subsurface layer, so that this layer showed the greatest variability (Fig. 6). The lowest value $\left(10\right.$ ind $\left.\mathrm{m}^{-3}\right)$ was found at S13 in March and at S14 in November. Maximum values frequently occurred at S14, with 3048 ind $\mathrm{m}^{-3}$ in September 1988; 1269 ind $\mathrm{m}^{-3}$ in April 1986; 758 ind $\mathrm{m}^{-3}$ in June 1988; and at S13 (1218 ind $\left.\mathrm{m}^{-3}\right)$ in October 1985; and S12 (783 ind $\mathrm{m}^{-3}$ ) in August 1986. Values were lower and more uniform at 200$300 \mathrm{~m}$; a maximum of 818 ind $\mathrm{m}^{-3}$ was noted at S14 in April 1986. Tintinnid abundance was low and uniform in all deeper layers (Fig. 6), but increased occasionally in the deepest layers (800-1000 m) of the South Adriatic Pit. 

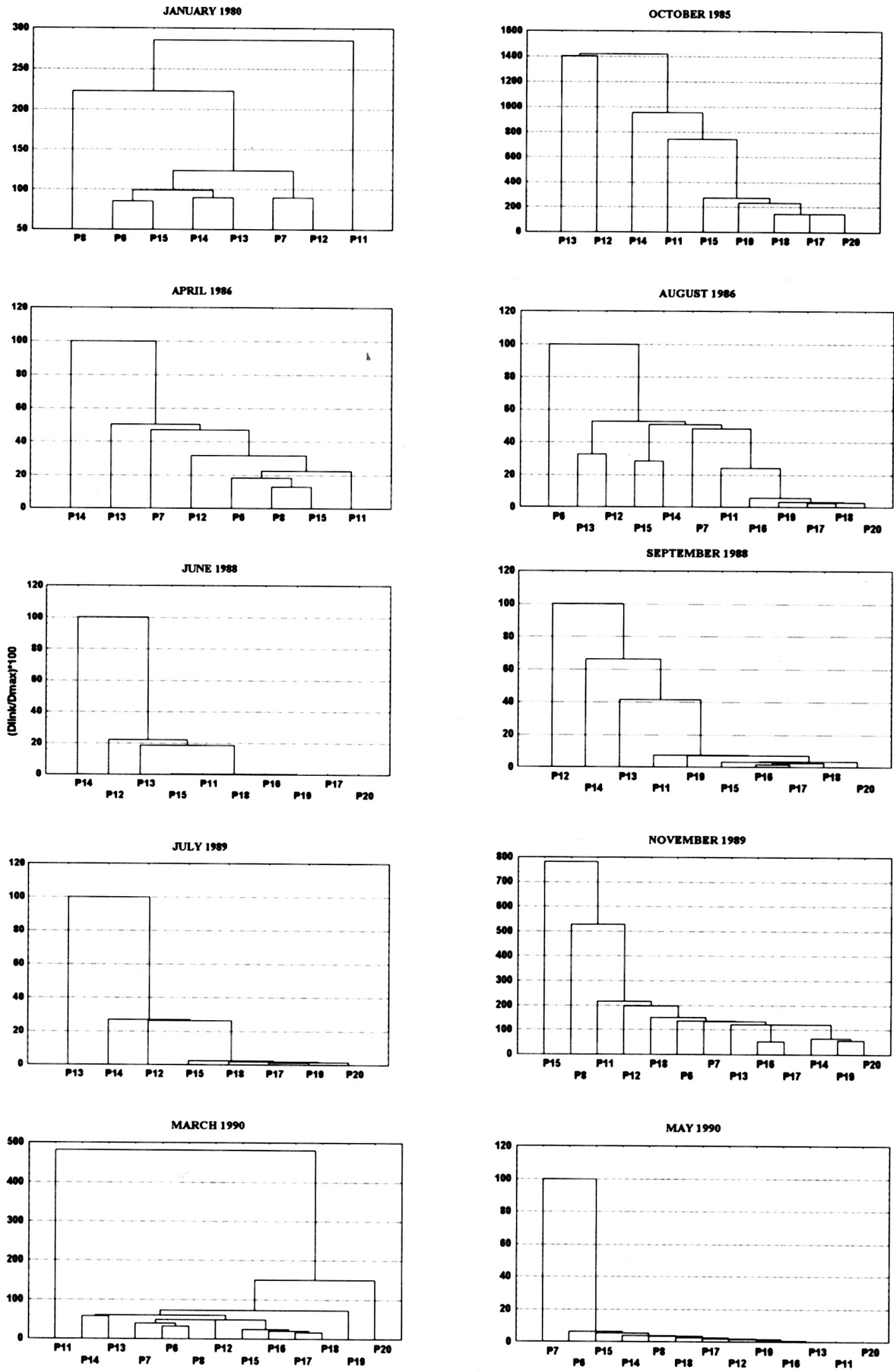

FIG. 4. - Cluster analysis for each cruise based on total tintinnids abundance. 


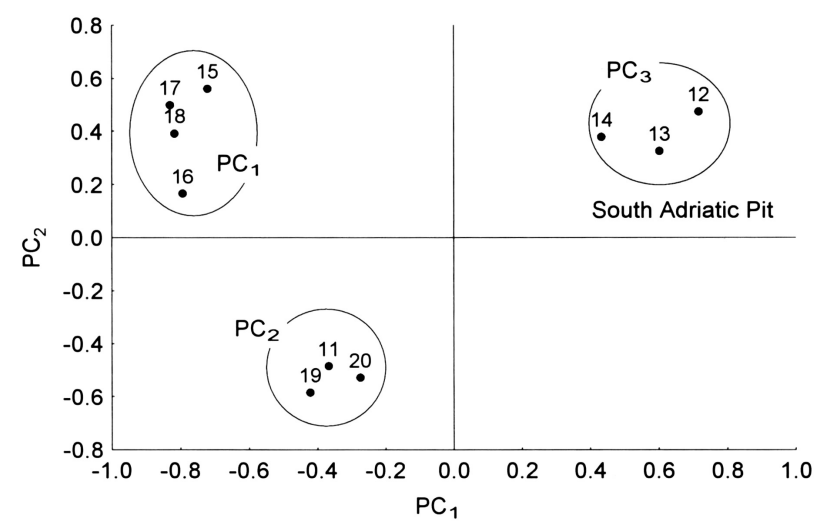

FIG. 5. - Spatial representation (in coordinate PC frame) of factor loadings of three significant PCs. The total tintinnid abundances were used. The number above the circles indicates the station number.

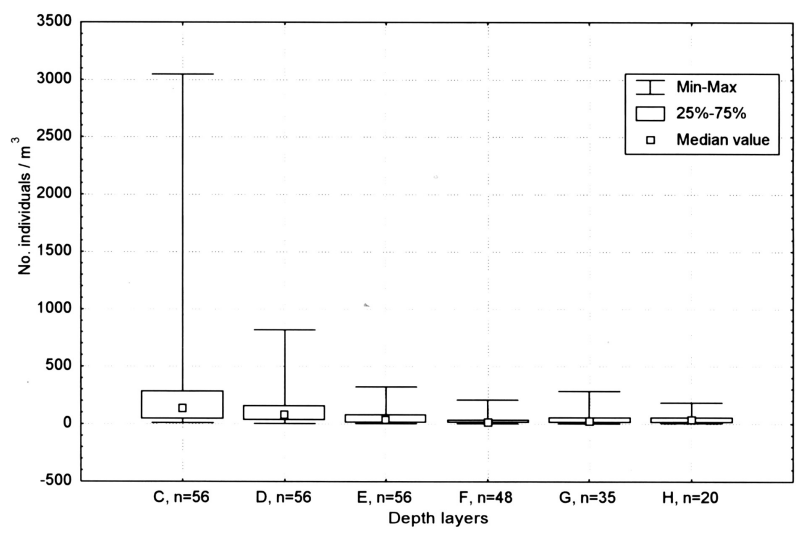

FIG. 6. - Box diagram of non-transformed data for the total number of tintinnids in different layers (C, 100-200 m; D, 200-300 m; E, 300-400 m; F, 400-600 m; G, 600-800m; H, 800-1000 m).

\section{Dominant species in surface and subsurface layers}

Figure 7 shows the percentage contribution of the three dominant species, Dictyocysta mitra, Codonella aspera, and Undella claparedei (syn. Proplectella, see the revision of the family
Undellidae, Balech, 1975), within surface and subsurface layers, as well as their relationship to other species. In the surface layer, these species accounted for $20-91 \%$ (average: $51.8 \%$ ) of the total tintinnid abundance; in the subsurface layer, this figure ranged from 29 to $79 \%$ and averaged $52.9 \%$. D. mitra was markedly predominant in June 1988, accounting for $68.4 \%$ of the total tintinnids in the subsurface layer. A maximum of 33,024 ind $\mathrm{m}^{-3}$ was found at station S14. C. aspera predominated in March 1990, accounting for $45.3 \%$ of tintinnids in the surface layer; but the highest density (860 ind $\mathrm{m}^{-3}$ ) was noted in October 1985 (S13). U. claparedei accounted for $60.5 \%$ of subsurface specimens in April 1986, with a maximum of 1960 ind $\mathrm{m}^{-3}$ at S14. In addition to the three species mentioned above, 10 additional species accounted for over $5 \%$ of the total tintinnids at one time or another. Tintinnopsis angulata, for example, was $43 \%$ of the total numbers in August 1986; and Xystonella lohmanni was $46 \%$ (2816 ind $\mathrm{m}^{-3}$ ) of tintinnids in the surface layer in July 1989 at S13.

\section{Dominant species in mesopelagic layers}

D. mitra and $U$. claparedei were always present from 100 to $400 \mathrm{~m}$ (layers C, D and E), namely at stations located at over $400 \mathrm{~m}$. Higher contributions of these species to the population of deep-sea tintinnids occurred only when they were dominant in surface layers (Fig. 8). D. mitra accounted for 53\% of all species in these layers in June 1988; U. claparedei accounted for 69\% of this group in April 1996. The characteristic mesopelagic species Parundella lohmanni was constantly present at $1-83 \%$, with an average of $35.7 \%$. This species was especially abundant in August 1986 and September 1988, with the

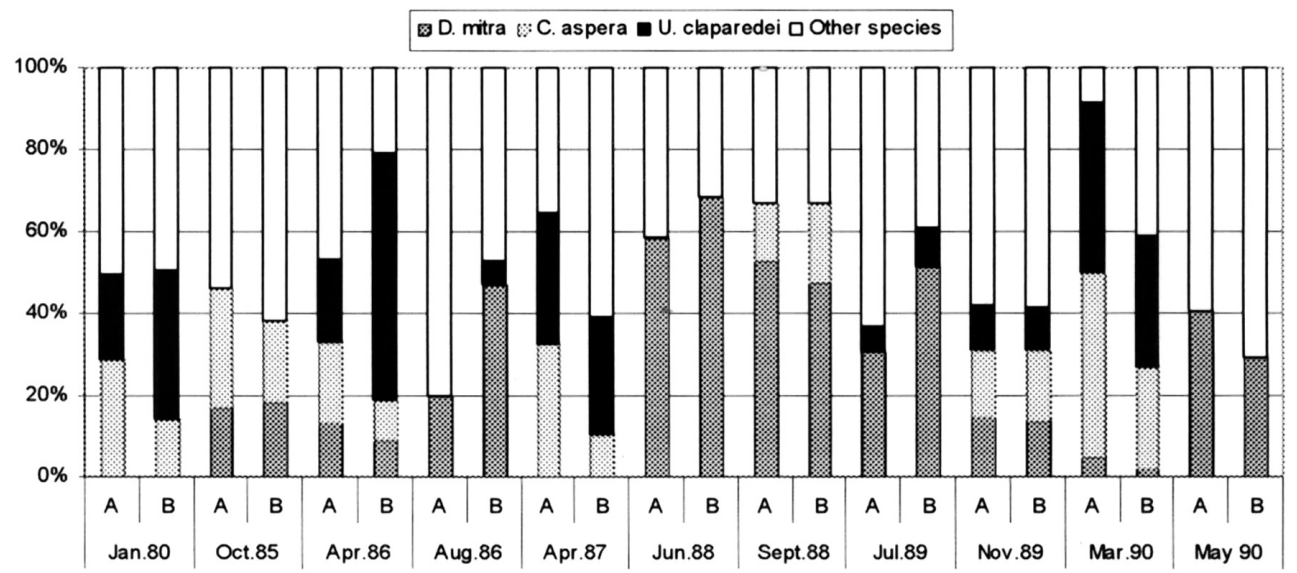

FIG. 7. - Percent contribution of dominant species to the total number of tintinnids in 0-50 m layer (A), and 50-100 m layer (B). 


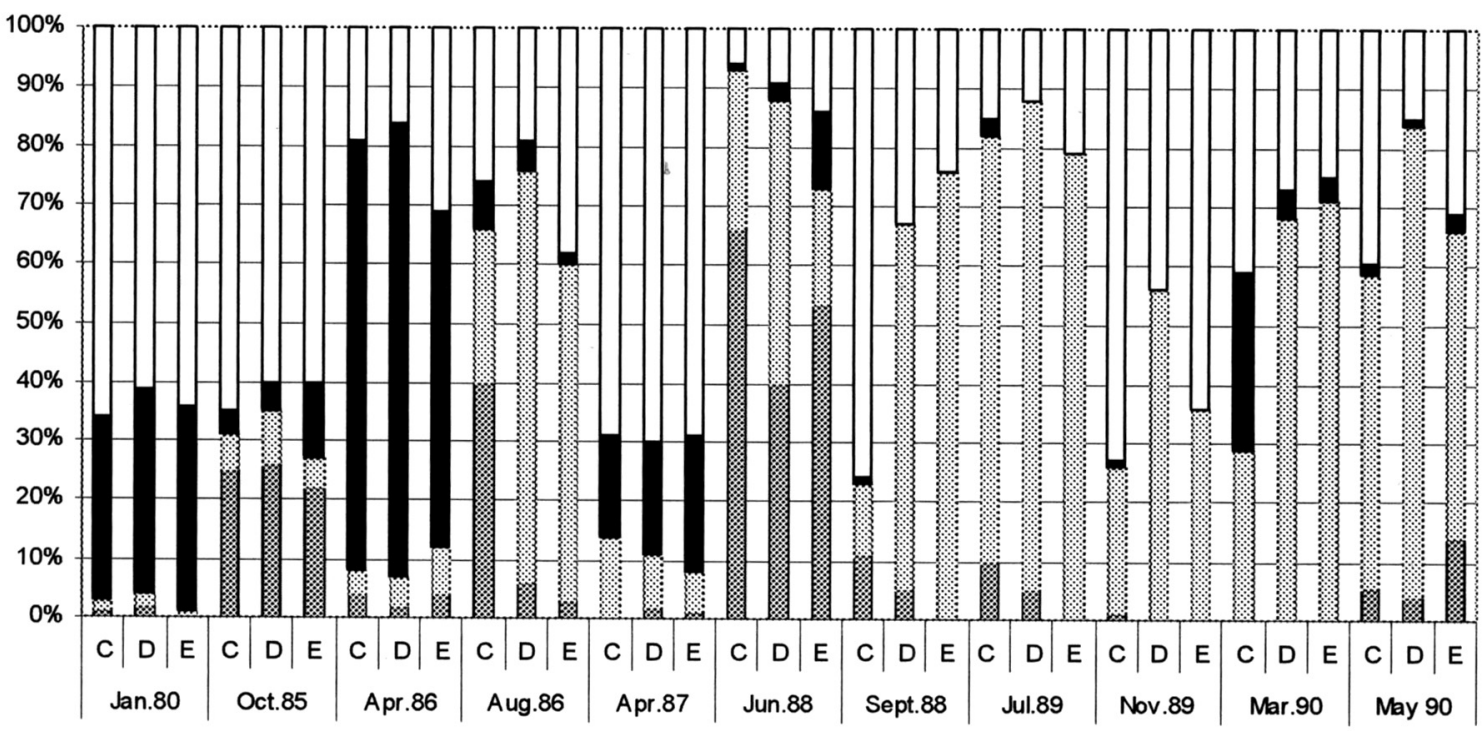

FIG. 8. - Percent contribution of dominant species to the total number of tintinnids in 100-200 m layer (C); 200-300 m layer (D); $300-400 \mathrm{~m}$ layer (E).

highest density, 280 ind $\mathrm{m}^{-3}$, at station $\mathrm{S} 12$ from 300 to $100 \mathrm{~m}$. Xystonellopsis cymatica accounted for 6 to $10 \%$ of tintinnids in August 1986, November 1989, and May 1990. The species Codonella amphorella occurred with a frequency of 28 to $32 \%$ in April 1987. Pethalotricha ampulla was $45 \%$ of the total tintinnine community (2265 ind $\mathrm{m}^{-3}$ ) from 100 to 200 m only in September 1988.

\section{Dominant species in deep-sea layers}

Xystonellopsis scypium was encountered regularly between 400 to $1000 \mathrm{~m}$ (layers F, G and H). This included those stations at which the total depth exceeded $600 \mathrm{~m}$. It was the dominant deep-sea tintinnid (53 to 79\%) in August 1986, and from June 1988 to May 1990 (Fig. 9). The two highest densities were 150 ind $\mathrm{m}^{-3}$ at station S7 in August 1986

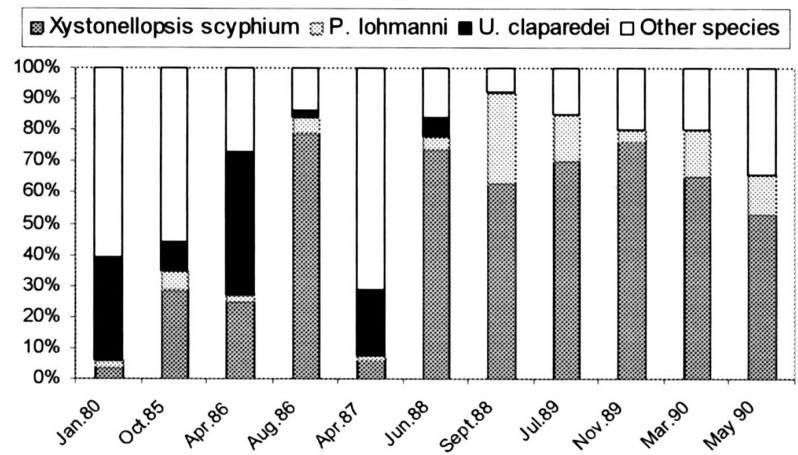

FIG. 9. - Percent contribution of dominant species to the total number of tintinnids in layers between 400 to $1000 \mathrm{~m}$. between 600 to $800 \mathrm{~m}$; and 180 ind $\mathrm{m}^{-3}$ at $\mathrm{S} 13$ between 800 to $1000 \mathrm{~m}$. The other important deepsea species, Xystonellopsis aciculifera, was also most abundant in August 1986, with 7\% of the tintinnid population and with a maximum value of 14 ind $\mathrm{m}^{-3}$ at $\mathrm{S} 13$ from 400 to $600 \mathrm{~m}$ depths. Parundella lohmanni and Undella claparedei are also important in deep-sea layers when they are most abundant in the mesopelagic or sub-surface layer. Furthermore, in April 1987 Codonella amphorella averaged $40 \%$ of the total deep-sea tintinnids.

\section{DISCUSSION}

The plankton net used in this work was suitable for evaluating the larger individuals of tintinnid populations, but no estimates could be done to quantify small species, such as Dadayiella ganymedes, which passed through the net. Nevertheless, studies on these smaller species using the 250-1 plankton trap "Adriatic" (Kršinić, 1990; Kršinić, unpublished data), have demonstrated that many of these are rare in the open waters of the South Adriatic. Thus, despite this shortcoming, the present data still permit a valuable quantitative description of the relative abundance relationships of this group over space and time. A comparison between the results of the numerical abundance of open-sea tintinnids presents difficulties due to differences in sampling methods. 
In addition, sampling problems for research below $200 \mathrm{~m}$ depths are an important reason for the very poor knowledge of deep-sea communities.

An abundance of 33 ind $1^{-1}$ for only one species, Dictyocysta mitra, in the 100 to $50 \mathrm{~m}$ layer is especially noteworthy for an oligotrophic oceanic region. A maximum abundance of 35 ind $\mathrm{l}^{-1}$ of total tintinnids in the central area of the South Adriatic was noted in September 1993, using the plankton trap "Adriatic" at 50 m depths (Kršinić, unpublished data). Tintinnid concentrations in open Mediterranean waters are generally 25 ind $1^{-1}$ (Dolan, 2000), and in the south-western Atlantic Ocean the concentrations only average about 11 ind $1^{-1}$ with a maximum of 59 ind $1^{-1}$ (Thompson et al., 1999). In the North Aegean, the dominant species Codonella galea exceeds 30 ind $1^{-1}$ at the surface, but in the South Aegean, tintinnids showed a very low abundance (Pitta and Giannakourou, 2000). Abundance of tintinnines along coastal sites of the western Mediterranean was lower than that found in the Gulf of Naples. In this gulf, open-sea species were present in very high values, for example Dictyocysta mitra 120 ind $\mathrm{l}^{-1}$ and Rhabdonella coni-

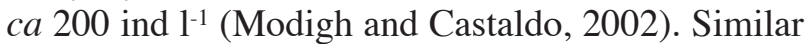
to these findings, certain open-sea species were recorded in much higher numbers in the eastern part of the northern Adriatic than in their natural niche, the surface layer of the southern Adriatic. Amphorides laackmanni, usually a very rare oceanic species, was present with a maximum of 890 ind $1^{-1}$ (Kršinić and Precali, 1997).

From about 100 species of tintinnids registered in the Adriatic Sea (Entz, 1904, 1909; Laackmann, 1913; Jörgensen, 1924; Kršinić, 1980), none of the estuarine-neritic species of the genera Tintinnopsis, Stenosemella, Metacylis, Helicostomella, Favella were found during the present research, which indicates that the central part of the southern Adriatic and the area around the Palagruža Sill are not influenced by coastal waters from the eastern and western Adriatic. The inflow of water masses from the Mediterranean Sea is an important factor that determines the qualitative composition of the distribution of surface and sub-surface tintinids in the South Adriatic. The highest total number of tintinnid species per cruise occurred in January 1980, October 1985, and November 1989. In each case, this can be related to an intrusion of Levantine Intermediate Water (LIW) (Vilibić and Orlić, 2001). The ingression of LIW was accompanied by a wealth of oceanic tintinnids throughout the entire region, especially at central deep-sea stations. However, ingressions did not increase species diversity to the same extent. This points to the fact that in April 1987 and June 1988, the whole vertical transect was occupied by a significant fraction of LIW, while tintinnid fauna was very poor. This perhaps is due to the qualitative composition of the species in the source area, the Ionian Sea. According to Dolan et al. (1999), the diversity of tintinnids appeared higher in the central and eastern basins, as compared to the west Mediterranean. All mesopelagic and deep-sea species, like the dominant surface and subsurface species, were permanent inhabitants of the South Adriatic Pit. The advection of inflowing water masses imposed a longitudinal type of horizontal distribution on surface and subsurface tintinnid populations of the South Adriatic. This was characterized by a higher diversity of species and the relatively low abundance in all layers at the central stations. The open-sea tintinnid species in the southern Adriatic are regenerated from time to time with the LIW water mass (Kršinić and Grbec, 2002). The extent of the incursion also affected the distribution of oceanic tintinnids in the Middle and North Adriatic. The highest species diversity in the North Adriatic was observed in 1990, with a maximum of 13 species in October (Kršinić and Precali, 1997).

A South Adriatic cyclonic gyre was the result of an inflowing current along the eastern coast, and an outflow along the western coast. Aspects of the bottom topography that separate the Middle Adriatic from Mediterranean influences (Orlić et al., 1992), also appear to play a role in this process. Gyre formation in the central region of the southern Adriatic Pit is responsible for the "eddy type" distribution of surface and subsurface tintinnids. This results in a decrease in the number of species and an increase in population densities in the core of the eddy. It also inhibits the transport of tintinnids towards the Middle and North Adriatic. In addition, the high abundance of tintinids in the surface or subsurface layers is linked to the tintinnid abundances of the mesopelagic layer. Similarly, the density of specimens in mesopelagic layers was reflected in deepsea layers. Comments on the vertical distribution and characteristic species of this area are found in previous works (Kršinić, 1988, 1998; Kršinić and Grbec, 2002).

The two above mentioned different types of horizontal distribution of oceanic tintinnines in surface and subsurface layers coincide with two seasons. During the fauna-poor summer and autumn, the 
highest abundance of tintinnids was found at central stations. However, the highest species diversity was noted during winter and early spring for the entire area of the southern Adriatic, and the highest abundance at the perimeter stations on the eastern (S11) and western Adriatic coast (S15). The results of this research are in accordance with those previously reported for the eastern coastal area of the Adriatic. In the Dubrovnik coastal area, the oceanic tintinnid fauna was quite diverse from November to midMarch, with an average of 20 species per sample, and a minimum of only 2 species per sample, which occurred from June to August. The highest abundances were noted at the same time, a first maximum of 4300 ind. $\mathrm{m}^{-3}$ in November and the second of 2900 ind. $\mathrm{m}^{-3}$ in February (Kršinić, 1980). In the period from 1996 to 1997 at the same station off Dubrovnik, the oceanic tintinnids were of qualitative-quantitative importance only from December to February, when a maximum 11300 ind. $\mathrm{m}^{-3}$ in midDecember was registered in layers from 50 to $25 \mathrm{~m}$ depths (Kršinić, unpublished data).

The outflow of eutrophic North Adriatic waters along the west coast of the Adriatic, and their sinking in the area of the Bari Canyon (Vilibić and Orlić, 2001), encouraged an increase in the population densities of some species of oceanic tintinnids (S14). Therefore, it may be assumed that mesopelagic and deep-sea tintinnids apparently depend on food resources transported by sinking mid-Adriatic waters along the western outer edge of the eddy. This was shown in April and August 1986, September 1988, July 1989, and again in March 1990.

The dramatic change in the qualitative composition of tintinnids makes 1988 stand out as an exceptional year. June 1988 showed the greatest impoverishment of the species in the South Adriatic, accompanied by changes in the qualitative composition and structure of the dominant species. The abundant subsurface species Undella claparedei almost disappeared, and Dictyocysta mitra increased significantly. In the same year, a nanophytoplankton bloom was noted in the western region of the North Adriatic in late spring and at the beginning of summer; which contributed to high levels of detritus aggregates (Degobbis, 1989). According to Šolić and Krstulović (1991), the number of heterotrophic bacteria at one station in the eastern part of the Palagruža Sill was 7 times greater than the mean value for the period 1968-1979. After 1987, a remarkable change in the deep thermohaline circulation of the eastern Mediterranean occurred as a con- sequence of the different water exchange regimes between the Ionian and Levantine Basin and the Adriatic Sea (Klein et al., 1999). According to Vilibić and Orlić (2001), in April 1987 dense water sank to the bottom of the South Adriatic Pit and then flowed out to the Ionian Sea. Characteristic small copepod species also sank towards the southern part of the Pit and the Strait of Otranto (Kršinić and Grbec, 2002). It can be assumed that the occurrence of anomalous cooling and mixing at surface and subsurface layers in the South Adriatic Pit in April 1987 could be responsible for the diversity of oceanic tintinnids. This thermohaline stress is perhaps the reason for the negative influence on the immigration of surface and subsurface oceanic tintinnids in the region. In the 1989-1990 cruises, the LIW fraction distribution was similar once more to the situation in 1980 and 1985, which influenced a more similar qualitative composition of the tintinnid population.

According to Buljan (1968), Pucher-Petković (1971) and Vučetić (1973), the South Adriatic Pit is the most impoverished zone of the Adriatic Sea. According to Viličić et al. (1998), the South Adriatic is oligotrophic with $<0.2 \mu \mathrm{mol} \mathrm{l}^{-1} \mathrm{PO}_{4}$ and $<3 \mu \mathrm{mol}$ $1^{-1} \mathrm{NO}_{3}$. During April 1987, when a microphytoplankton bloom was registered for the first time in the South Adriatic (Viličić et al., 1989), chlorophyll $a$ exceeded $3 \mathrm{mg}$ chl $a \mathrm{~m}^{-3}$ (Marasović et al., 1999). This was accompanied by an atypical distribution of tintinnids, with relatively low abundance in the surface layer. However, in April 1986, a relatively high abundance of tintinnines in both surface layers was noted simultaneously with lower concentrations of chlorophyll $a$, about $0.5 \mathrm{mg} \operatorname{chl} a \mathrm{~m}^{-3}$, but with a greater part of the phytoplankton being nanophytoplankton (Marasović et al., 1999). Nanophytoplankton manifested less marked oscillation than microphytoplankton in the central area of the South Adriatic. The nanophytoplankton biomass was generally lower in winter and higher in spring and autumn (Viličić, 1985). During the microphytoplankton bloom, it thus seems likely that conditions for the development of oceanic tintinnids towards the deepest part of the South Adriatic were not optimal as in the post-bloom period, during the re-mineralization process of particular organic matter. The South Adriatic Pit, in contrast with other regions, is characterized by higher particulate organic carbon (POC) and low primary production. This phenomenon is related to the erratic nutrient supply which contains stagnant water in the centre of the gyre (Faganeli et al., 1989). 
Accordingly, it seems reasonable to conclude that the horizontal distribution of oceanic surface and subsurface tintinnids in the oligotrophic region of the South Adriatic Pit are influenced by Mediterranean water masses and the formation of a cyclonic gyre. The dense bottom waters from the middle Adriatic reach the western part of the pit and enrich deep layers with organic detritus important for the autochthonous populations of mesopelagic and deep-sea tintinnids.

\section{ACKNOWLEDGEMENTS}

Many thanks are due to the personnel of the Hydrographic Institute of the Republic of Croatia in Split for the hydrographical data. We would like to thank anonymous reviewers for their critical reviews and suggestions for improving this paper. The research was supported by the Ministry of Science, Education and Sports of the Republic of Croatia.

\section{REFERENCES}

Balech, E. - 1959. Tintinnoinea del Mediterraneo. Trab. Inst. Esp. oceanogr., 28: 1-88.

Balech, E. - 1968. Algunas especies nuovas o interesante de Tintinnidos del Golfo México y Caribe. Rev. Mus. Arg. Cien. Nat. "B. Rivadavia" Hidrobiol., 2: 165-197.

Balech, E. - 1975. La familia Undellidae (Protozoa, Ciliophora, Tintinnina). Physis Seccion A. 34: 377-398

Bićanić, Z. - 1993. Some physical and oceanographical characteristics of the Otranto Strait. Acta. Geogr. Croat., 28: 99-112. (in Croatian).

Brandt, K. - 1906. Die Tintinnodeen der Plankton-Expedition Tafelerklärungen kurze Diagnose der neuen Arten. Ergebn. Atlant. Plankton Exped., 3(L.a.): 33 pp, 70 pls.

Brandt, K. - 1907. Die Tintinnodeen der Plankton-Expedition. Systematischer Teil. Ergebn. Atlant. Plankton Exped., 3(L.a.): $1-449$.

Buljan, M. - 1968. Fluctuation on oceanographic properties of the Central Adriatic in the period 1962-1967. Pomorski Zbornik. 6: 845-864. (in Croatian).

Buljan, M. and M. Zore-Armanda. 1976. Oceanographical properties of the Adriatic Sea. Oceanogr. Mar. Biol. Ann. Rev., 14: 11-98.

Burkill, P. H. - 1982. Ciliates and other microplankton components of a nearshore food-web: Standing Stocks and production processes. Ann. Inst. Océanogr. Paris. 58 (suppl.): 335-350.

Capriulo, G. and E. Carpenter. - 1983. Abundance, species composition and feeding impact of tintinnid micro-zooplankton in central Long Island Sound. Mar. Ecol. Prog. Ser., 10: 277-288.

Cordeiro, T. A., F. P. Brandini and P. Martens. - 1997. Spatial distribution of the Tintinnina (Ciliophora, Protista) in the North Sea, spring of 1986. J. Plankton Res., 19: 1371-1383.

Daday, E. - 1886. Ein kleiner Beitrag zur Kenntniss der Infuzorien. Fauna des Golfes von Neapel. Mitth. Zool. Sta. Neapel. 6: 481-498.

Daday, E. - 1887. Monographie der Familie der Tintinnodeen. Mitth. Zool. Sta. Neapel. 7: 473-591.

Degobbis, D. - 1989. Increased eutrophication of the Northern Adriatic Sea. Second Act. Mar. Polut. Bull., 20: 452-457.

Dolan, J.R. - 2000. Tintinnid ciliate diversity in the Mediterranean
Sea: longitudinal patterns related to water column structure in late spring-early summer. Aquat. Microb. Ecol., 22: 69-78.

Dolan, J.R., F. Vidussi and H. Claustre. - 1999. Planktonic ciliates in the Mediterranean Sea: longitudinal trends. Deep-Sea Research I. 46: 2025-2039.

Entz, G., Jr. - 1904. A Quarnero Tintinnidai. All. Közl., 3: 121-133.

Entz, G., Jr. 1909. Studien über Organisation und Biologie der Tintinniden. Arch. Protistenkd., 15: 94-226.

Faganeli, J., M. Gačić, A. Malej and N. Smodlaka. - 1989. Pelagic organic matter in the Adriatic Sea in relation to winter hydrographic conditions. J. Plankton Res., 11: 1129-1141.

Jörgensen, E. - 1924. Mediterranean Tintinnidae. Report on the Danish oceanographical expeditions 1908-10 to the Mediterranean and adjacent seas. II Biology. 1-110.

Hargraves, P.E. - 1981. Seasonal variation of tintinnids (Ciliophora: Oligotrichida) in Narraganset Bay, Rhode Island. U.S.A. J. Plankton Res., 3: 81-91.

Klein, B., W. Roether, B.B. Manca, D. Bregant, V. Beitzel, V. Kovačević and A. Luchetta. - 1999. The large deep-water transient in the Eastern Mediterranean. Deep-Sea Res. I. Oceanogr. Res. Papers. 46: 371-414.

Kofoid, C.A. and A.S. Campbell. - 1929. A conspectus of the marine and fresh-water ciliata belonging to the suborder Tintinnoinea, with descriptions of new species principally from the Agassiz Expedition to the Eastern Tropical Pacific 1904 1905. Univ. of Calif. Publ. in Zoology. 34: 1-403.

Kofoid, C.A. and A.S. Campbell. - 1939. The Ciliata: the Tintinnoinea. Boul. Mus. Comp. Zool. Harvard. 84: 1-473.

Kršinić, F. - 1980. Qualitative and quantitative investigations of the tintinnids along the eastern coast of the Adriatic. Acta Adriat., 21: 19-104 (in Croatian)

Kršinić, F. - 1982. On vertical distribution of Tintinnids (Ciliata, Oligotrichida, Tintinnina) in the open waters of the southern Adriatic. Mar. Biol., 68: 83-90.

Kršinić, F. - 1987. On the ecology of tintinnids in the Bay of Mali Ston (Eastern Adriatic). Est., Coast. Shelf Sci., 24: 401-418.

Kršinić, F. - 1988. The family Xystonellidae (Ciliophora, Tintinnina) in the Adriatic Sea. J. Plankton Res., 10: 413-429.

Kršinić, F. - 1990. A new type of zooplankton sampler. J. Plankton Res., 12: 337-343.

Kršinić, F.-1998. Vertical distribution of protozoan and microcopepod communities in the South Adriatic Pit. J. Plankton Res., 20: 1033-1060.

Kršinić, F. and R. Precali. - 1997. On the occurrence of oceanic tintinnids with particular consideration of the species Amphorides laackmanni (Jörgensen, 1924), (Ciliophora, Oligotrichida, Tintinnina) in the northern Adriatic Sea. P.S.Z.N.I.: Marine Ecology. 18: 67-81.

Kršinić, F. and B. Grbec. - 2002. Some distributional characteristics of small zooplankton at two stations in the Otranto Strait (Eastern Mediterranean). Hydrobiologia. 482: 119-136.

Laackmann, H. - 1910. Die Tintinnodeen der deutschen Südpolar Expedition 1901-1903. Deutsche Südp. Exped., 11: 340-496.

Laackmann, H. - 1913. Adriatische Tintinnodeen. Sitzungsber. Akad Wiss. Wien Math. Naturwiss. K1. 122:1-45.

Laval-Peuto, M. - 1981. Construction of the lorica in Ciliata Tintinnina. In vivo study of Favella ehrenbergii: variability of phenotypes during the cycle, biology, statistics, biometry. Protistologica. 17: 242-279.

Laval-Peuto, M. and C. D. Brownlee. - 1986. Identification and systematics of the Tintinnina (Ciliophora): Evaluation and suggestions for improvement. Ann. Inst. océanogr. Paris. 62: 69-84.

Marasović, I., D. Viličić, and Ž. Ninčević. - 1999. In MalanotteRizzoli, P. and V.N. Eremeev (eds.), South Adriatic ecosystem: interaction with the Mediterranean Sea. pp. 383-405. Kluwer Academic Publishers, Dodrecht.

Modigh, M. and S. Castaldo. - 2002. Variability and persistence in tintinnid assemblages at a Mediterranean coastal site. Aquat. Microb. Ecol., 28: 299-311.

Modigh, M., S. Castaldo, M. Saggiomo and I. Santarpia. - 2003. Distribution of tintinnid species from $42^{\circ} \mathrm{N}$ to $43^{\circ} \mathrm{S}$ through the Indian Ocean. Hydrobiologia. 503: 251-262.

Orlić, M., M. Gačić and P.E. La Violette. - 1992. The current and circulation of the Adriatic Sea. Oceanologica Acta. 15: 109-124.

Paranjape, M.A. - 1987. The seasonal cycles and vertical distribution of tintinnids in Bedford Basin, Nova Scotia, Canada. Can. J. Zool., 65: 41-48.

Pierce, R.W. and Turner, J.T. - 1993. Global biogeography of 
marine tintinnids. Mar. Ecol. Prog. Ser., 94: 11-26.

Pitta, P. and A. Giannakourou. - 2000. Planktonic ciliates in the oligotrophic Eastern Mediterranean: vertical, spatial distribution and mixotrophy. Mar. Ecol. Prog. Ser., 194: 269-282.

Pitta, P., A. Giannakourou and U. Christaki. - 2001. Planktonic ciliates in the oligotrophic Mediterranean Sea: longitudinal trends of standing stocks, distributions and analysis of food vacuole contents. Aquat. Microb. Ecol., 24: 297-311.

Pucher-Petković, T. - 1971. Recherches sur la production primaire et la densité des populations du Phytoplancton en Adriatique moyenne (1962-1967). Rapp. P.-v.Réun comm. Int. Explor. Scient. Mer Mediterr., 20: 339-343.

Richman, R.W. - Rotation of principal components. J. Climatol., 3 : 293-335.

StatSoft Inc. - 2000 STATISTICA for Windows [Computer program manual]. Tulsa, OK: StatSoft, Inc., 2300 East 14th Street, Tulsa, OK 74104, phone: (918) 749-1119, fax: (918) 749-2217, email: info@statsoft.com, WEB: http://www.statsoft.com.

Šolić, M. and N. Krstulović. - 1991. Time series of heterotrophic bacteria density in central Adriatic Sea. Cont. Shelf Res., 11: 397-407.

Thompson, G.A., V.A. Alder, D. Boltovskoy and F. Brandini. 1999. Abundance and biogeography of tintinnids (Ciliophora) and associated microzooplankton in the Southwestern Atlantic Ocean. J. Plankton Res., 21: 1265-1298.

Verity, P.G. - 1986. Growth rates of natural tintinnid populations in Narragansett Bay. Mar. Ecol. Prog. Ser., 29: 117-126.
Verity, P.G. and D.K. Stocker. - 1982. Effects of Olisthodiscus luteus on the growth and abundance of tintinnids. Mar. Biol., 72: 79-87.

Vilibić, I. and M. Orlić. - 2001. Last-squares tracer analysis of water masses in the South Adriatic (1967-1990). Deep-Sea Res. I. 48: $2297-2330$

Vilibić, I. and M. Orlić. - 2002. Adriatic water masses, their rates of formation and transport through the Otranto Strait. Deep-Sea Res. I. 49: 1321-1340.

Viličić, D. - 1985. An examination of cell volume in dominant phytoplankton species of the middle and southern Adriatic waters. Int. Revue ges. Hydrobiol., 70: 829-843.

Viličić, D., Z. Vučak, A. Śkrivanić and Z. Gržetić. - 1989. Phytoplankton blooms in the oligotrophic open south Adriatic waters. Marine Chemistry. 28: 89-107.

Viličić, D., N. Leder and Z. Gržetić. - 1998. A study of microphytoplankton across the longitudinal front in the Strait of Otranto (May 1990). Period. Biol., 100: 53-58.

Vučetić, T. - 1973. Zooplankton and the circulation pattern of the water masses in the Adriatic. Netherlands J. Sea Res., 7: 112-121.

Zore-Armanda, M. - 1963. Les masses d'eau de la mer Adriatique. Acta Adriat., 10: 1-88.

Zore-Armanda, M. - 1968. The system of currents in the Adriatic Sea. Stud. Rev. Gen. Fish Counc. Medit., 34: 1-48.

Scient. ed.: D. Vaqué 